\title{
Glycemic profile, inflammatory markers, biochemical and histopathological parameters of mice fed with fermented dairy beverage with clove essential oil
}

Perfill glicêmico, marcadores inflamatórios, parâmetros bioquímicos e histopatológicos de camundongos alimentados com bebida láctea fermentada com adição de óleo essencial de cravo da índia

Perfil glucémico, marcadores inflamatorios, parámetros bioquímicos e histopatológicos de ratones alimentados con bebida láctea fermentada con aceite esencial de clavo

Keicy Sandy Silvestre de Souza ORCID: https://orcid.org/0000-0003-3992-7789 Universidade Federal de Minas Gerais, Brazil E-mail: keicysandy@yahoo.com.br

Anna Christina de Almeida ORCID: https://orcid.org/0000-0001-9836-4117 Universidade Federal de Minas Gerais, Brazil E-mail: aca2006@ica.ufmg.br

Stephanie Pedrosa de Oliveira ORCID: https://orcid.org/0000-0001-6763-8496 Universidade Federal de Minas Gerais, Brazil E-mail: stephanie_pedrosa_92@ hotmail.com Igor Viana Brandi ORCID: https://orcid.org/0000-0001-6714-7996 Universidade Federal de Minas Gerais, Brazil E-mail: ibrandi@hotmail.com

Sérgio Henrique Sousa Santos ORCID: https://orcid.org/0000-0002-7788-5447 Universidade Federal de Minas Gerais, Brazil E-mail: sergiosousas@hotmail.com

Francine Souza Alves Fonseca ORCID: http://orcid.org/0000-0002-5815-4550 Universidade Federal de Minas Gerais, Brazil

E-mail: francinefonseca@yahoo.com.br

Eliane Macedo Sobrinho Santos ORCID: https://orcid.org/0000-0002-1576-4957 Instituto Federal do Norte de Minas Gerais, Brazil

E-mail: eliane.santos@ifnmg.edu.br Janaína Ribeiro Oliveira ORCID: https://orcid.org/0000-0002-0411-545X Universidade Estadual de Montes Claros, Brazil E-mail: jana.mg@hotmail.com

Daniela Fernanda de Freitas ORCID: https://orcid.org/0000-0002-1050-5964 Universidade Estadual de Montes Claros, Brazil

E-mail: danielafernandadefreitas@gmail.com

Deborah de Farias Lelis ORCID: https://orcid.org/0000-0003-1136-8591 Universidade Estadual de Montes Claros, Brazil

E-mail: dehlelisfarias@gmail.com Daniel Silva Moraes

ORCID: https://orcid.org/0000-0002-2815-5640 Universidade Estadual de Montes Claros, Brazil

E-mail: silvamoraes.daniel@gmail.com

João Matheus de Almeida Silva ORCID: https://orcid.org/0000-0001-5308-682X Centro Universitário FIP Moc, Brazil E-mail: jmasmc1999@gmail.com 


\author{
Cintya Neves Souza \\ ORCID: http://orcid.org/0000-0002-3640-8636 \\ Universidade Federal de Minas Gerais, Brazil \\ E-mail: cintyamicro@hotmail.com \\ Paula Karoline Soares Farias \\ ORCID: https://orcid.org/0000-0003-0529-2754 \\ Universidade Federal de Minas Gerais, Brazil \\ E-mail: paulaK.soares@hotmail.com \\ Raphael Rodrigues Porto \\ ORCID: https://orcid.org/0000-0003-1603-9615 \\ Universidade Federal de Uberlândia, Brasil \\ E-mail: raphael.porto@ufu.br \\ Hércules Otacilio Santos \\ ORCID: https://orcid.org/0000-0001-5399-9522 \\ Instituto Federal do Norte de Minas Gerais, Brazil \\ E-mail: htacilio@hotmail.com
}

\begin{abstract}
Previous studies have shown that the clove essential oil concentration of $200 \mathrm{mg} / \mathrm{kg}$ did not present toxicity and histopathological changes in the liver. Based on the evidence presented in this study, we decided to evaluate in vivo the ability of a previously developed fermented dairy beverage, tested only in vitro, in which the standard chemical preservative, potassium sorbate, was replaced by clove essential oil $(2 \mu \mathrm{l} / \mathrm{ml})$, to be a functional food. To this end, twenty-four male Swiss mice were divided into three groups and submitted insulin sensitivity (IST) and glucose tolerance (GTT) testing, evaluation of physiological and biochemical parameters, histopathological analysis and quantification of the expression of anti-inflammatory and pro-inflammatory cytokines in the liver, after administering daily of the fermented dairy beverage with or without clove essential oil by gavage during 30 days. The group that received the fermented dairy beverage with clove essential oil showed a lower glycemic level in GTT, a higher sensitivity to insulin and a higher glucose decay constant rate (Kitt), with relation to the other groups. In the evaluation of physiological parameters there were no signs of toxicity in the mice during the experimental period. The biochemical parameters, histopathological analysis and expression of anti-inflammatory (IL-10) and pro-inflammatory (IL1 $\beta$, IL6 e TNF $\alpha$ ) cytokines in the liver of the mice, was not significantly affected by the treatment. These results corroborated by bioinformatics analysis demonstrate that the fermented dairy beverage with clove essential oil it can function as a substitute for conventional chemical preservatives and reduce glycemic levels.
\end{abstract}

Keywords: Syzygium aromaticum; Glucose tolerance; Insulin sensitivity; Cytokines; Hepatotoxicity.

\title{
Resumo
}

Estudos anteriores demonstraram que o óleo essencial de cravo da índia na concentração de $200 \mathrm{mg} / \mathrm{kg}$ não apresentou toxicidade e alterações histopatológicas no fígado. Com base nas evidências apresentadas neste estudo, decidimos avaliar in vivo a capacidade de uma bebida láctea fermentada desenvolvida e testada anteriormente apenas in vitro, na qual o conservante químico padrão, sorbato de potássio, foi substituído por óleo essencial de cravo ( $2 \mu \mathrm{l} / \mathrm{ml})$, para ser um alimento funcional. Para isso, vinte e quatro camundongos Swiss machos foram divididos em três grupos e submetidos a testes de sensibilidade à insulina (TSI) e tolerância à glicose (TTG), avaliação de parâmetros fisiológicos e bioquímicos, análise histopatológica e quantificação da expressão de antiinflamatórios e pró-citocinas inflamatórias no fígado, após administração diária da bebida láctea fermentada com ou sem óleo essencial de cravo da índia por gavagem durante 30 dias. O grupo que recebeu a bebida láctea fermentada com esse óleo essencial apresentou menor nível glicêmico no TTG, maior sensibilidade à insulina e maior taxa constante de decaimento da glicose (Kitt), em relação aos demais grupos. Na avaliação dos parâmetros físiológicos não houve indícios de toxicidade nos camundongos durante o período experimental. Os parâmetros bioquímicos, a análise histopatológica e a expressão das citocinas antiinflamatórias (IL-10) e pró-inflamatórias (IL1 $\beta$, IL6 e TNF $\alpha$ ) no fígado dos camundongos não foram significativamente afetados pelo tratamento. Esses resultados corroborados por análises de bioinformática demonstram que a bebida láctea fermentada com óleo essencial de cravo da india pode funcionar como substituto dos conservantes químicos convencionais e reduzir os níveis glicêmicos.

Palavras-chave: Syzygium aromaticum; Tolerância a glicose; Sensibilidade a insulina; Citocinas; Hepatotoxicidade.

\section{Resumen}

Estudios previos han demostrado que la concentración de aceite esencial de clavo de $200 \mathrm{mg} / \mathrm{kg}$ no presenta toxicidad y cambios histopatológicos en el hígado. Con base en la evidencia encontrada en este estudio, decidimos evaluar in vivo la capacidad de una bebida láctea fermentada desarrollada previamente, probada solo in vitro, en la que el conservante químico estándar, sorbato de potasio, fue reemplazado por aceite esencial de clavo ( $2 \mu \mathrm{l} / \mathrm{ml})$, para ser un alimento funcional. Con este fin, veinticuatro ratones suizos se dividieron en tres grupos y se sometieron a pruebas de sensibilidad a la insulina (ITS) y tolerancia a la glucosa (GTT), evaluación de parámetros fisiológicos y bioquímicos, análisis histopatológico y cuantificación de la expresión de antiinflamatorios y pro- citocinas - 
inflamatorias normativas, después de la administración después de la administración administración de bebida láctea fermentada con o sin aceite esencial de clavo por sonda durante 30 días. El grupo que bebió la leche italiana fermentado con aceite esencial de clavo presentó menor nivel de glucemia en el GTT, mayor sensibilidad a la insulina y mayor tasa constante de desintegración de glucosa (Kitt), en relación a los otros grupos. En la evaluación de los parámetros fisiológicos, no hubo evidencia de toxicidad en los ratones durante el período experimental. Parámetros bioquímicos, análisis histopatológico y expresión de citocinas antiinflamatorias (IL-10) y proinflamatorias (IL1 $\beta$, IL6 y $\mathrm{TNF} \alpha$ ) en el hígado de ratones no afectados por el tratamiento. Estos resultados corroborados por análisis bioinformáticos demuestran que la bebida láctea fermentada con aceite esencial de clavo puede actuar como sustituto de los conservantes químicos convencionales y reducir los niveles glucémicos.

Palabras clave: Syzygium aromaticum; Tolerancia a la glucosa; Sensibilidad a la insulina; Citoquinas; Hepatotoxicidad.

\section{Introduction}

Medicinal plants with broad therapeutic spectra are used to prevent and cure various pathologies (Dhama et al., 2018). The clove (Syzygium aromaticum) stands out as one of the traditional spices used in food preservation and has potent antioxidant and antimicrobial activities. Its benefits are linked to its phytoconstituents, including its essential oils (EOs) (Cortés-Rojas et al., 2014).

Natural products and chemical-free consumptions are being increasingly valued. Among them, the fermented dairy beverage produced from whey is a viable food alternative, as it reduces the environmental impact caused by the discarded whey. It thus has low cost and a high nutritional value. When it is supplemented with clove essential oil as a natural preservative, it can be considered a functional food, because the clove essential oil can modify gastrointestinal tract physiology, alter biochemical parameters and reduce and minimize the effects of some pathologies (Cortés-Rojas et al., 2014; Di Cerbo et al., 2017).

Farias (2016), in order to obtain a natural product and free from chemical additives, used the formulation of the fermented dairy beverage developed by the study group in Biotechnology (GEBIO), from the Agrarian Sciences Institute Federal University of Minas Gerais (ICA-UFMG) and replaced the chemical preservative, potassium sorbate, with the clove essential oil, in three different concentrations. Analyzes of the antioxidant and antimicrobial activity of the oil present in the beverage were carried out for 28 days. A product was obtained with antioxidant and antimicrobial power that can be functional without needing to add preservatives or chemical additives.

The Food and Drug Administration (FDA) recognizes clove essential oil as Generally Recognized as Safe (GRAS) under prescribed conditions and when it is included in the food for which it is intended (Food and Drug Administration FDA, 2018). For clove EO to gain approval for addition to fermented dairy beverage and be classified as a functional product, in vivo toxicity studies must be carried out to evaluate the EO pharmacological activities exerted on the organism and to determine if this concentration will produce any toxic effects (Agência Nacional de Vigilância Sanitária, 2015; Food and Drug Administration FDA, 2018).

In the literature, although previous studies have evaluated the Syzygium aromaticum essential oil used in different pharmacological activities in mice (Al-Okbi et al., 2014; Liu et al., 2015). The concentration of $2 \mu 1 / \mathrm{mL}$ did not present acute or chronic toxic effects or cause histopathological changes in the liver, kidney, brain, lung, heart, or spleen (Liu et al., 2015).

Through this previous study (Liu et al., 2015), the concentration in the beverage of $2 \mu 1 / \mathrm{mL}$ can be adopted in this experiment, without the need to perform a toxicity test previously. To date, no in vivo experiments have reported using it as a preservative in fermented dairy beverage.

Therefore, the present study aimed was to evaluate the modulation of the glycemic profile, physiological and biochemical parameters, histopathological analysis, bioinformatics analysis and quantification of the expression of anti- 
inflammatory and pro-inflammatory cytokines, in the liver male Swiss mice feed with fermented dairy beverage supplemented with clove essential oil.

\section{Methodology}

\section{Preparation, caloric determination, and physico-chemical analyses of the fermented dairy beverage}

The fermented dairy beverage and the fermented dairy beverage with Syzygium aromaticum essential oil were prepared weekly in triplicate at the Food Technology Laboratory (Agrarian Sciences Institute - Federal University of Minas Gerais, ICA/UFMG), according with the methodology proposed by (Farias, 2016; Figueiredo et al., 2019), with a few modifications, in the proportions provided in the legislation (Brasil, 2005, 2007).

Both beverages contained $44.5 \%$ whole milk UHT, $44.5 \%$ reconstituted whey powder (15\%), $10 \%$ crystal sugar, $1 \%$ modified starch, and $0.1 \%$ thermophilic DVS lactic culture. For the fermented dairy beverage control, the chemical preservative potassium sorbato $(0.003 \mathrm{~g} / \mathrm{mL})$ was added. In the test group, clove essential oil $(2 \mu \mathrm{l} / \mathrm{ml})$ was added to the fermented dairy beverage instead.

To make each beverage, two blends were produced. The first was composed of UHT milk, modified starch and sugar, which was homogenized with to the magnetic stirrer and heated until the temperature reached $37{ }^{\circ} \mathrm{C}$, as checked with a digital thermometer. The second mixture, containing previously homogenized reconstituted whey powder and mineral water, was added to the first mixture and heated to precisely $42{ }^{\circ} \mathrm{C}$, then the lactic culture was added and homogenized. $50 \mathrm{~mL}$ of each drink was transferred to falcon tubes for $\mathrm{pH}$ measurement on a benchtop $\mathrm{pH}$ metre, and stored in the BOD incubator at $43{ }^{\circ} \mathrm{C}$. The $\mathrm{pH}$ was measured every hour and when it reached 4.6, the beverages were cooled in a refrigerator until reaching $5{ }^{\circ} \mathrm{C}$. The formed clot was agitated and undone. Then, either $2 \mu \mathrm{l} / \mathrm{mL}$ Syzygium aromaticum fermented dairy beverage with clove essential oil or $0.003 \mathrm{~g} / \mathrm{mL}$ potassium sorbate used as a chemical additive was added to the fermented dairy beverage. The drinks were agitated so that the oil and the preservative were homogeneously distributed and stored in sterile vials in quantity for daily use at $5{ }^{\circ} \mathrm{C}$.

The physico-chemical analyses were carried out in the Bromatology Laboratory (Agrarian Sciences Institute - Federal University of Minas Gerais, ICA/UFMG). They were quantified by titulometry, titratable acidity, and the protein content by the Kjeldahl method, and the lipid contents were assessed by the Mojonnier method, according to Normative Instruction $\mathrm{n}^{\circ} .68$ of the Ministério da Agricultura Pecuária e Abastecimento - MAPA (Brasil, 2006).

The microbiological analyses were performed at the Animal Sanity Laboratory of the Center for Agrarian Sciences Research-CPCA. To investigate the Salmonella sp. presence, the total and thermotolerant coliforms and milk bacteria counts were assessed according to the methodologies described in the MAPA Normative Instructions $n^{0}$. 62/2003 (Brasil, 2003), 68/2006 (Brasil, 2006) e 46/2007 (Brasil, 2007). Both analyses were completed before the beverages were released for animal consumption.

The caloric value of the beverage was determined through calorimetric analysis in the Bromatology Laboratory (Agrarian Sciences Institute - Minas Gerais Federal University ICA/UFMG in Montes Claros). Ten $\mathrm{mL}$ of each beverage were placed in petri dishes and stored in a forced circulation oven at $65{ }^{\circ} \mathrm{C}$ for $24-48$ hours until a constant weight was obtained in order to remove excess moisture and obtain the total solids according to an adapted methodology (Souza et al., 2018). The total solids were transferred to a crucible and placed in the adiabatic calorimetric pump IKA C5000® in order to obtain the calories amount per drinks gram. The beverage were standardized so that the diets were isocaloric. 


\section{Animals}

This study was approved by the Animal Experimentation Ethics Committee of the Federal University of Minas Gerais - CEUA/UFMG, under protocol number 231/2017 and by the Ethics Committee on Experimentation and Animal Welfare of the State University of Montes Claros - Unimontes, under process number 149/2017.

The animal experimentation used 24 four-week-old male Swiss mice from the Animal Experimentation Center of the State University of Montes Claros - Unimontes, where the study was carried out according to the National Council for the Control of Animal Experimentation (CONCEA) (Brasil, 2015).

The animals went through a seven-day adaptation period, were fed ad libitum with a standard diet (LABINA®), containing $23.3 \%$ proteins, $55.6 \%$ carbohydrates and $2.6 \%$ lipids, and $4.0 \mathrm{kcal} / \mathrm{g}$ total energy. And had free access to tap water.

At four weeks of age, the animals were divided into three groups ( $\mathrm{n}=8$ animals each), completely randomized design and fed the respective experimental diets for four weeks. In order for the diets to be isocaloric and the three groups would consume the same amount of Kcal daily, the feed was given to each group in a controlled manner and the water was supplied ad libitum. The diets were adjusted weekly according to the average body weight of the animals in each group, measured once a week.

In the control group (Ctrl), the animals were fed only with standard diet (LABINA®). In group, fermented dairy beverage (FDB), the animals were given standard diet plus the fermented dairy beverage. In group, fermented dairy beverage with the addition of clove essential oil (FDB+CEO), the animals were given standard diet plus the fermented dairy beverage with the addition of clove essential oil.

The group FDB animals received $2 \mathrm{~mL}$ fermented dairy beverage by gavage and the group FDB+CEO animals received $2 \mathrm{~mL}$ fermented dairy beverage with the Syzygium aromaticum essential oil by gavage, daily at 07:00 AM for 30 days.

After euthanized, blood samples were collected at the time of decapitation and centrifuged (3000 rpm for 10min at $4^{\circ} \mathrm{C}$ ). The serum was separated and stored at $-20{ }^{\circ} \mathrm{C}$, for biochemical analysis. The liver were rapidly removed, weighed, and divided into eppendorf tubes. One part was stored in $10 \%$ formaldehyde for histopathology analysis, the second part was frozen in liquid nitrogen for and subsequently stored at $-80^{\circ} \mathrm{C}$, for RNA extraction.

\section{Metabolic, toxicity, biochemical and histopathological analysis}

The glycemic profile was performed on the 21st and 23rd experiment days at the capillary glycemia level. To evaluate the peripheral insulin sensitivity and glucose tolerance, insulin sensitivity (IST) and glucose tolerance (GTT) tests were performed.

The IST was done in the morning of the 21 st experiment day with animals in the fed state, by the intraperitoneal application 0.75 UI of insulin/kg body weight (Vinué \& González-Navarro, 2015). The glucose decay constant rate (Kitt) was calculated using the formula $0.693 / \mathrm{t}_{1 / 2}$, in which the blood glucose was obtained by the analysis of the slope of the linear regression obtained by the linear constant from 0 to 15 minutes after insulin administration (Bonora et al., 1989).

The GTT was performed on the 23rd experiment day in animals that had fasted for 6 hours, through the intraperitoneal application $2 \mathrm{~g}$ of glucose/kg body weight (Jørgensen et al., 2017).

Both measurements of blood glucose were performed using the portable glucometer and the glycemic strips of the Alere $\mathrm{G} 2 \AA$ according to the manufacturer's specifications. Blood drops were collected from a small cut at the tail, and these samples were used to check the glycemia before the application time, at time 0 , and at 15, 30, 60 and 120 minutes after the application. 
During the study period, the animals were observed for signs of toxicity: locomotion, behavior, breathing, changes in skin and hair, eyes, tremors, salivation, diarrhea, lethargy, drowsiness, and rated at scores from 0 to 4. 0: absent, 1: rare, 2: slightly, 3: moderate, 4 severe (Malone \& Robichaud, 1962).

Serum creatinine, alanine aminotransferase (ALT), aspartate aminotransferase (AST), albumin, total cholesterol, high density lipoprotein (HDL), and glucose, were measured using enzymatic tests (Wiener BT-3000 Plus Chemistry Analyzer Wiener, Argentina).

The right lobe of the liver were fixed in $10 \%$ formaldehyde solution and embedded in paraffin. Sections were deparaffinized, rehydrated, and stained with hematoxylin and eosin (H\&E). Five Images of liver areas ( $\times 10$ ocular and $\times 40$ objective lenses) were captured with an Olympus FSX 100 microscope, (Tokyo, Japan). Were evaluated hepatic steatosis, inflammation and fibrosis, and classified according to methodology adapted from (Brunt et al., 1999).

\section{Reverse transcription and real-time PCR (qRT-PCR)}

The liver tissue collected were homogenized and the total RNA was isolated using Trizol reagent (Invitrogen Corp. ${ }^{\circledR}$, USA), according to specification provided by the manufacturer. The quantification of RNA was measured at absorbance of 260 nm and $280 \mathrm{~nm}$ (A260/280) (Thermo Scientific- NanoDrop 2000®, USA). The total RNA samples were treated with Dnase, and reverse transcription was performed with M-MLV RT (Ludwig Biotec ${ }^{\circledR}$, Brazil) $e$ OligodT, using random hexamer primers. All samples were normalized to glyceraldehyde-3-phosphate dehydrogenase (GAPDH), which served as an endogenous control. The sequence of the primers were described in the Table 1: tumor necrosis factor alpha (TNF $\alpha)$

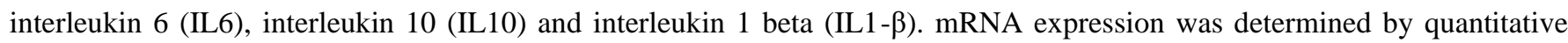
real-time reverse transcriptase PCR (qRT-PCR) using SYBR Green reagent ${ }^{\circledR}$ on the PlusOne platform (Applied Biosystems ${ }^{\mathrm{TM}}$ QuantStudio $^{\text {TM }} 6$ Flex Real-Time PCR System ${ }^{\circledR}$, USA). Normalization of the target genes to the reference gene was performed using the $2-\Delta \Delta C$ T method (Livak \& Schmittgen, 2001).

Table 1 - Sequence of specific oligonucleotide primers used in qRT-PCR.

\begin{tabular}{c|l|c}
\hline Genes & \multicolumn{1}{|c}{ Sequence primers } & \multicolumn{1}{|c}{ References } \\
\hline GAPDH & $\begin{array}{l}\text { F: 5' AAGAAGGTGGTGAAGCAGGCATC3' } \\
\text { R: 5' CGAAGGTGGAAGAGTGGGAGTTG3' }\end{array}$ & (Fan et al., 2020) \\
\hline \multirow{2}{*}{ TNF $\alpha$} & $\begin{array}{l}\text { F:5'CATCTTCTCAAAATTCGAGTGACAA3' } \\
\text { R: 5'TGGGAGTAGACAAGGTACAACCC3' }\end{array}$ & (Secchi et al., 2017) \\
\hline IL10 & $\begin{array}{l}\text { F:5'TGAGGCGCTGTCGTCATCGATTTCTCCC3' } \\
\text { R:5' ACCTGCTCCACTGCCTTGCT 3' }\end{array}$ & (Vo et al., 2017) \\
\hline IL1- $\beta$ & $\begin{array}{l}\text { F:5'ATGGCAACTGTCCCTGAACTCAACT3' } \\
\text { R: 5'CAGGACAGGTATAGATTCAACCCCTT 3' }\end{array}$ & (Bao et al., 2008) \\
\hline IL 6 & $\begin{array}{l}\text { F:5'GAGGATACCACTCCCAACAGACC3' } \\
\text { R:5'AAGTGCATCATCGTTGTTCATACA3' }\end{array}$ & (Murakami et al., 2011) \\
\hline
\end{tabular}

Source: Authors.

\section{Bioinformatics analyses}

The bioinformatic analysis was performed as previously described (Barbosa et al., 2019; Santos et al., 2017). Using the Genecards database (www.genecards.org version 4.14), we used the search terms "Syzygium aromaticum" AND glucose AND insulin. The initial gene list was then expanded using the STRING (version 11.0) (Szklarczyk et al., 2019), limited to the species "homo sapiens". Was considered the highest interaction score required (highest confidence 0.9), the maximum number of interactors in the first and second shell was no more than 20 and 10 interactors respectively. We select all active interaction sources. 
For each gene to be identified, we add the association scores obtained in the interaction network and adjust the score, multiplying by 1000 , to obtain the weighted number of links (WNL). According to WNL all genes were clustered, using Kmeans Clustering ( $\mathrm{p}$ <.001). The genes without interactions were defined as orphan genes. The genes with the highest rank of associations were identified as leader genes. Analyses were performed using SPSS (Version 18.0, IBM, New York, NY, USA).

\section{Statistical analysis}

The number of animals per group was determined a priori using a power calculation: $\mathrm{n}=1+\left[2 \mathrm{C} *(\mathrm{~s} / \mathrm{d})^{2}\right]$, where $\mathrm{C}=$ $(z \alpha+z \beta)^{2}$ and is dependent on the values chosen for the statistical power and level of significance, $s$ is the coefficient of variation, and $\mathrm{d}$ is the expected difference between the groups to obtain $\mathrm{p}<0.05$.

To evaluate the glucose concentration in the GTT and IST, two-way ANOVA was used. The area-under-curve of the GTT and IST were calculated by the trapezoidal method (Matthews et al., 1990).

For the glucose decay constant rate evaluation (Kitt) in the IST, linear regression analysis was completed by obtaining the constant value of the slope from 0 to 15 minutes using the formula $0.693 / \mathrm{t}_{1 / 2}$.

To evaluate the groups, one-way ANOVA was used. When there were differences between groups, at significance levels of 5\% ( $\mathrm{p}<0.05)$, the Tukey test was performed. All analyses used the program GraphPad Prism software (Version 7.0๑, San Diego, California, USA).

\section{Results}

In the glucose decay constant rate per minute evaluation (Kitt), the group FDB+CEO has shown higher Kitt of $11.4 \%$ (Table 2), compared to the other groups. However, up to 30 minutes there was no effect of the essential oil associated to the beverage in the glucose in the insulin sensitivity test (Table 2).

Table 2 - The glucose decay constant rate Kitt (\% per minute) during the insulin sensitivity test (Kitt, 15 minutes) per group.

\begin{tabular}{ccc}
\hline Group & $\begin{array}{c}\text { Kitt } \\
(0-15 \mathrm{~min})\end{array}$ \\
\hline Ctrl & $8.2 \%$ \\
FDB & $9.7 \%$ \\
FDB+ CEO & $11.4 \%$ \\
\hline
\end{tabular}

Ctrl - Control Group: diet with standard diet; FDB - Isocaloric group to Ctrl group: standard diet + fermented dairy beverage; FDB+CEO Isocaloric group to Ctrl group: standard diet + fermented dairy beverage with clove essential oil.

Values expressed by group as the mean \pm standard deviation.

Source: Authors.

In both groups, glucose concentration in the first 15 minutes declined linearly. After 120 minutes of insulin application, the glucose concentration in each group was close to the glucose level measured at the initial time (Figure 1A).

The groups fed with fermented dairy beverages (FDB and FDB+CEO) did not present statistical significance in the area under curve when compared with the control group (Figure 1B). FDB+CEO presented a smaller area, demonstrating that the beverage with clove essential oil can regulate the glucose level of the cells.

In the glucose tolerance test, the groups did not present significance at the times 0 and 120 minutes. Each group blood glucose $(\mathrm{mg} / \mathrm{dl})$, at 120 minutes, was close to baseline time 0 , indicating that the animals presented with normal glucose tolerance (Figure 1C). 
Figure 1C represents the groups glycemic curve as a function of time (minutes). The glucose maximum peak of groups Ctrl and FDB+CEO was at 30 minutes while that of group FDB was at 15 minutes.

In the area under curve analysis (Figure 1D), FDB+CEO presented a significant reduction in the glucose blood level when compared to groups FDB and FDB+CEO.

When we use the search the GeneCard input terms, 8 genes were obtained. After being expanded in the STRING database, we obtained the interatoma shown in the figure 1E and 1F. Based on the analysis of bioinformatics and on the WNL values, AKT1, PIK3CA, PIK3CB and PIK3R1 are the leader genes (Figure 1E and 1F). These genes are related to the PIK3/Akt insulin signaling pathway. The data obtained in the bioinformatics analysis corroborate the findings in the IST and GTT tests. This result suggests that the clove essential oil when added to the fermented dairy beverage promoted a reduction in the glucose blood level. 
Figure 1 - Modulation of glucose and insulin. (A) Mean glucose concentration (mg/dL). (B) Area Under Curve (AUC) of blood glucose (mg/dL) per group during an Insulin Sensitivity Test (IST), after the intraperitoneal application of insulin at a concentration of $0.75 \mathrm{UI} / \mathrm{kg}$ body weight, in relation to time (min). (C) Mean glucose concentration (mg/dL). (D) Area Under Curve (AUC) of blood glucose (mg/dL) per group during Glucose Tolerance Test (GTT), after the intraperitoneal application of glucose $(2 \mathrm{~g} / \mathrm{kg}$ body weight), in relation to time ( $\mathrm{min})$. (E) Leader genes in the protein interaction network formed from genes from GeneCards. (F) distribution of genes in relation to WNL (Weighted Number of Links).
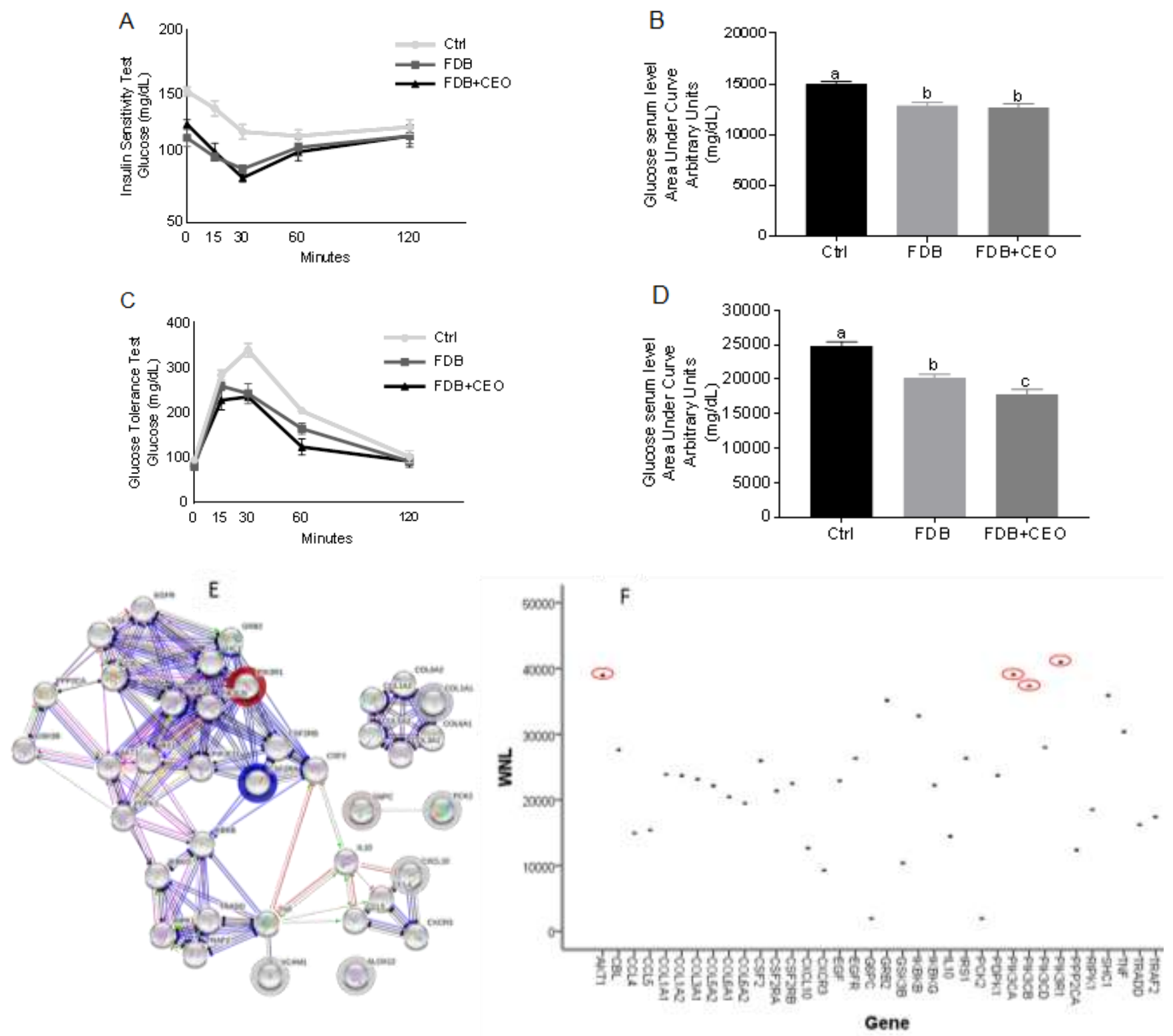

Control Group: diet with standard diet; FDB - Isocaloric group to Ctrl group: standard diet + fermented dairy beverage; FDB+CEO Isocaloric group to Ctrl group: standard diet + fermented dairy beverage with clove essential oil.

According to the results of the Tukey test $(\mathrm{p}<0.05)$, averages followed by the same letter did not differ from each other. Source: Authors.

Group FDB+CEO presented lower body weight in the third week compared to Ctrl group (Figure 2A). However, when we evaluate energy efficiency (Figure 2B) to exclude the possibility of body weight affecting the outcome of the tests IST e GTT, since this group presented a significant in the area under curve when compared with the control group as shown in Figures $1 \mathrm{~B}$ and $1 \mathrm{D}$. 
According to the data obtained, energy efficiency did not differ between groups at the end of the experiment. Thus the three groups were able to convert the nutrients provided by each diet into weight gain equally (Figura 2B).

The animals showed no clinical or behavioral changes, such as temperature, breathing, neurological, heart and respiratory rate, during the experimental period according to the methodology described by (Malone \& Robichaud, 1962) that indicated toxicity.

The integrity and function of hepatocytes was assessed by serum measurement of alanine aminotransferase (ALT) and aspartate aminotransferase (AST), albumin, total cholesterol, high-density lipoprotein (HDL) and triglycerides (Figure 2C and 2D).

The results indicate that the Group FDB + CEO did not show significant changes in the levels of ALT, AST, albumin, (Figure 2C), triglycerides, total cholesterol and HDL when compared to Group Ctrl (Figure 2D).

Figure 2 - Clinical and biochemical analysis. (A) Measurements of body weight of each group, from first to fourth week, according to the diet provided. (B) Energy efficiency of each group, evaluated at the end of the experiment, according to the body weight and kcal consumption provided by diets. (C) Effect of diets on biochemical parameters that assess hepatocyte integrity. (D): Effect of diets on biochemical parameters that assess hepatocyte functionality.
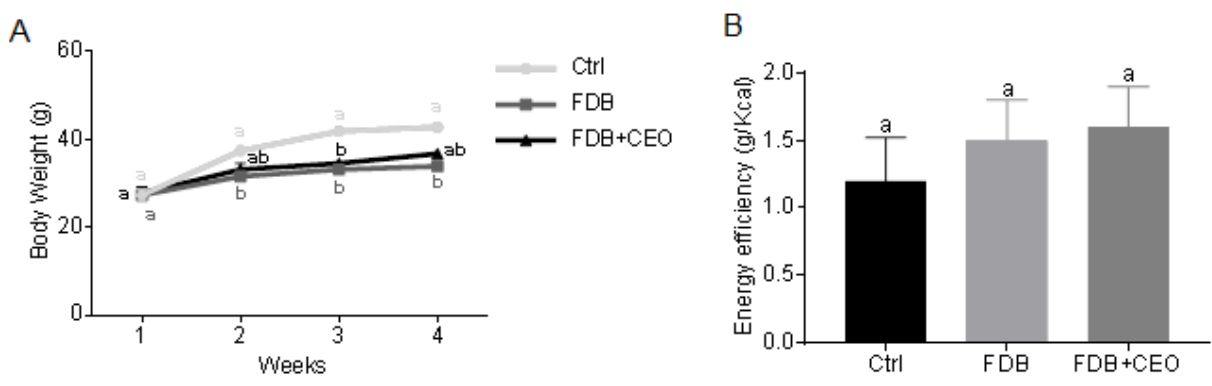

C
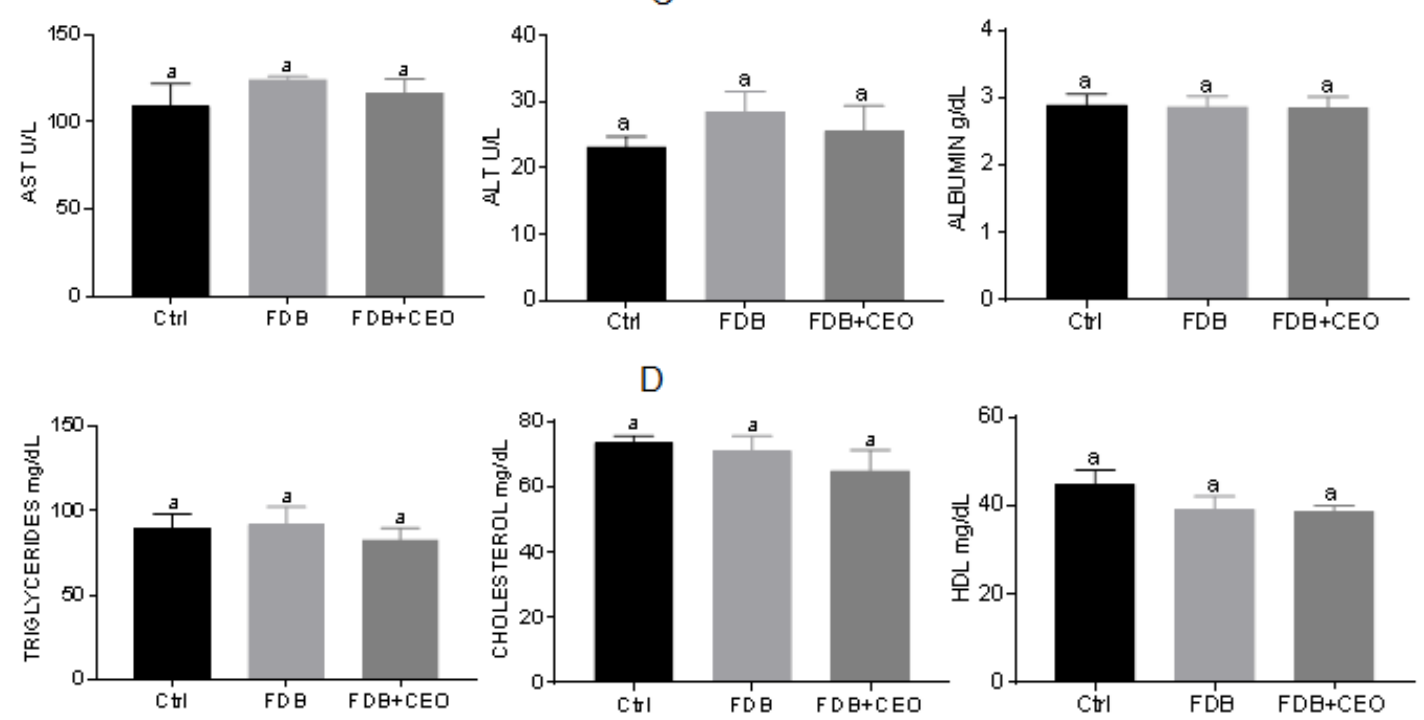

Ctrl - Control Group: diet with standard diet; FDB - Isocaloric group to Ctrl group: standard diet + fermented dairy beverage; FDB+CEO Isocaloric group to Ctrl group: standard diet + fermented dairy beverage with clove essential oil.

By the Tukey test ( $\mathrm{p}<0.05$ ), (A) averages followed by the same letter in the same week did not differ from each other. (B) averages followed by the same letter did not differ from each other. Source: Authors.

Histopathological analysis of the liver was performed using the general stratified score for morphological analysis of liver tissue, regarding the parameters of inflammation, steatosis and fibrosis (Figure 3). The analysis did not reveal 
histopathological alterations in liver tissue ( $p>0.05$ ), when evaluating the experimental groups (Figure 3). Thus, the drink did not produce lesions in the hepatocytes, complementing the biochemical findings that assessed liver function and integrity.

Figure 3 - Histopathological analysis. Stratified score for histopathological changes according to the different diets. Below the graph is illustrated the histopathology of the liver according to different diets.
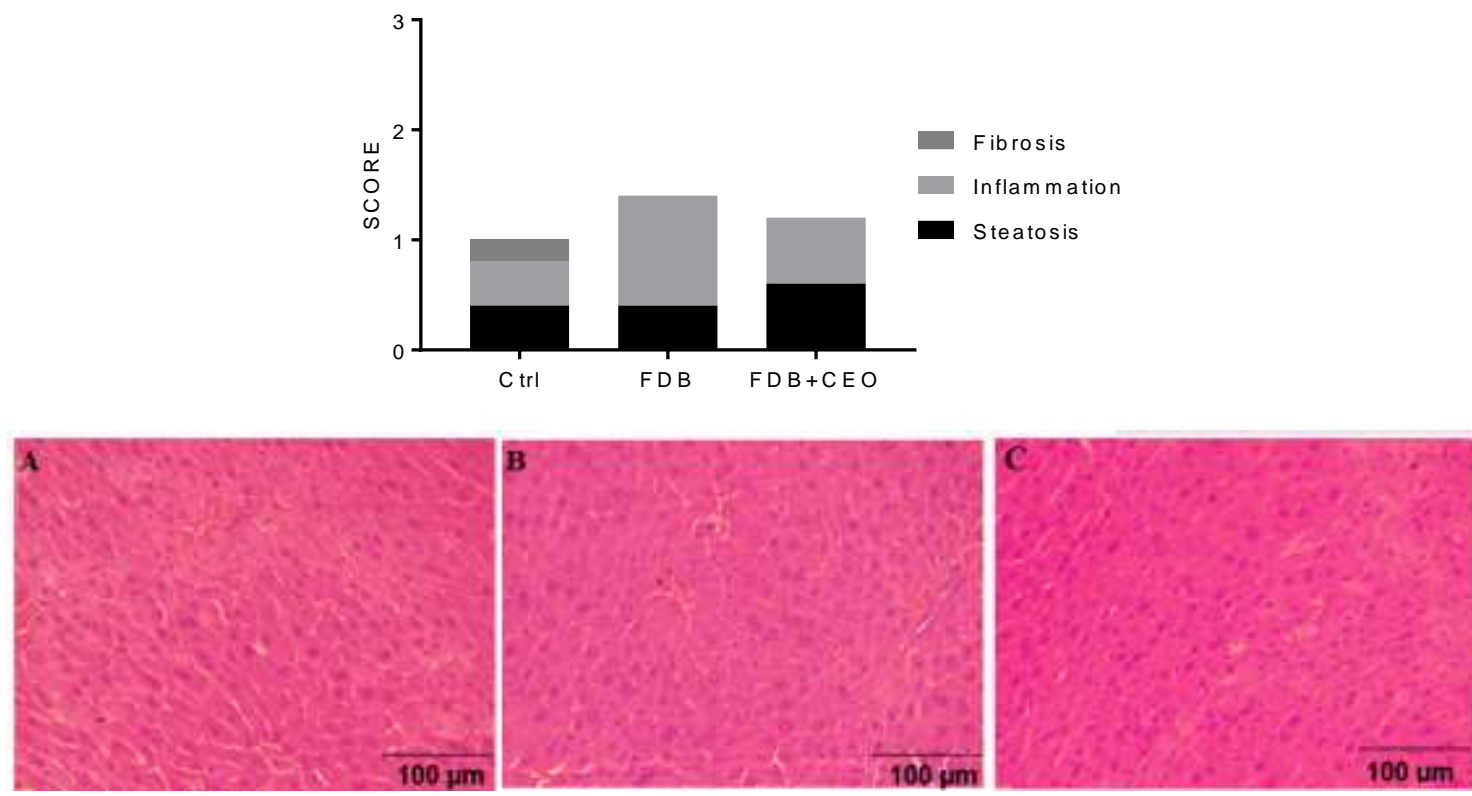

Coloring (H\&E) of the liver tissue, photos with 40x magnification. Average of scores 0 Absent changes $0,1-1,9$ slight changes 2 - 2,9 moderate changes $>/=3$ marked changes. Ctrl / A - Control Group: diet with standard diet; FDB / B - Isocaloric group to Ctrl group: standard diet + fermented dairy beverage; FDB+CEO / C - Isocaloric group to Ctrl group: standard diet + fermented dairy beverage with clove essential oil. Values expressed by group as the mean \pm standard deviation. Source: Authors.

The analysis of the expression of the pro-inflammatory and anti-inflammatory cytokine genes in the liver was important for evaluating the dose under study.

The results allowed to infer that the concentration of $2 \mu 1 / \mathrm{ml}$ of essential clove oil added to fermented dairy beverage did not induce hepatocyte lesions, since the concentration of pro-inflammatory cytokines, IL1 $\beta$, IL6 and TNF $\alpha$, and antiinflammatory, IL-10, (Figure 4) did not differ between the groups evaluated. 
Figure 4 - Levels of expression of the pro-inflammatory cytokines in the liver of mice according to different diets. (A) IL1 $\beta$, (B) IL6, (C) TNF $\alpha$ and (D) IL-10.
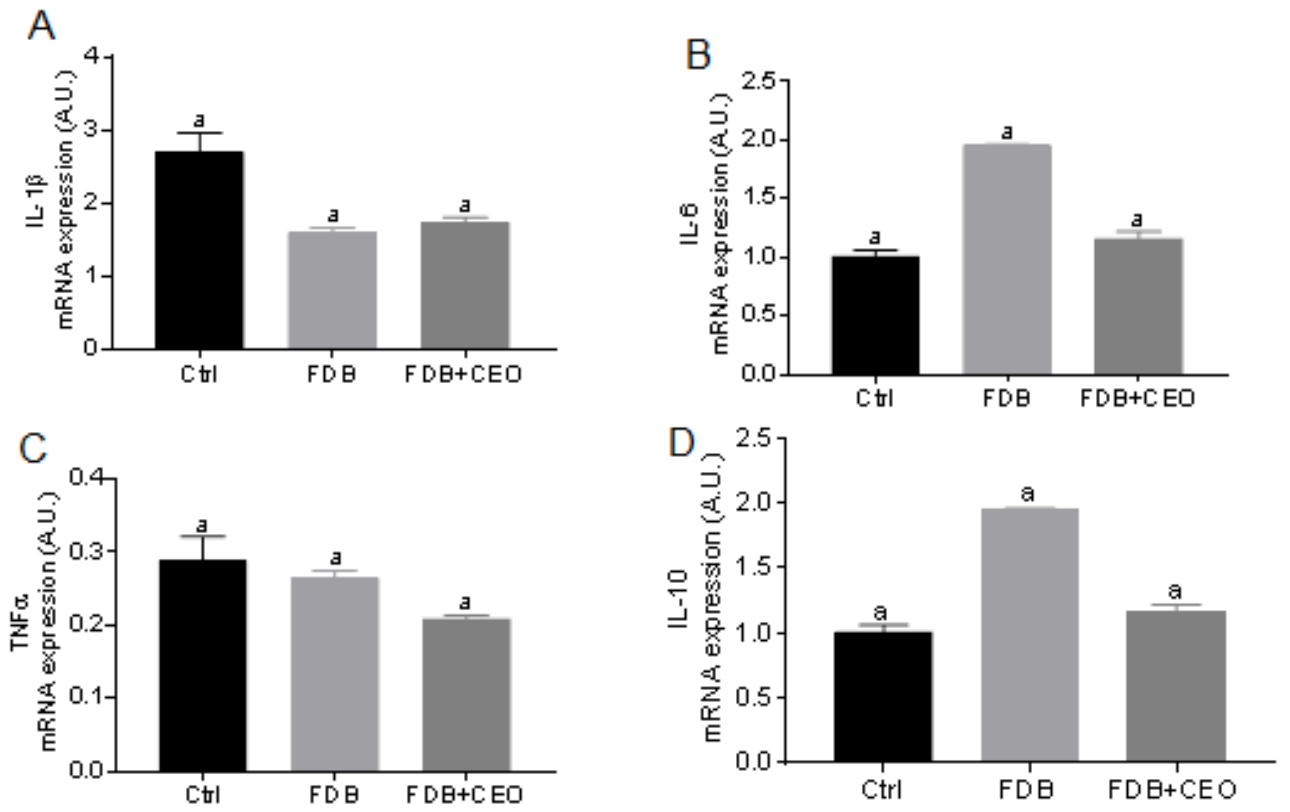

Ctrl - Control Group: diet with standard diet; FDB - Isocaloric group to Ctrl group: standard diet + fermented dairy beverage; FDB+CEO Isocaloric group to Ctrl group: standard diet + fermented dairy beverage with clove essential oil.

Values expressed by group as the mean \pm standard deviation. By the Tukey test ( $\mathrm{p}<0.05$ ), averages followed by the same letter did not differ from each other. Source: Authors.

\section{Discussion}

The glucose decay constant rate (Kitt) varies according to the stimulus produced in the cells by insulin, to capture circulating glucose and inhibit the production of hepatic glucose (Rines et al., 2016). This higher rate found in the FDB+CEO groups may have occurred because the clove EO exerts insulin-like activity in cells (Table 2).

The observed result was similar to those obtained by previous authors (Tu et al., 2014), who evaluated the ability of Syzygium aromaticum to regulate glucose consumption by $\mathrm{C}_{2} \mathrm{C}_{12}$ myocytes.

In the insulin sensitivity test, the three groups evaluated presented with similar behaviours, and the blood glucose $(\mathrm{mg} / \mathrm{dl})$ declined linearly in the first 15 minutes, before being reestablished to the value measured at time 0 in each group within 120 minutes (Figure 1A). This result was similar to that obtained in a study in which mice were induced to hypoglycemia by insulin. In the first 60 minutes after insulin application, their blood glucose declined, but it subsequently recovered after between 120 and 300 minutes (Kwiatkowski \& Antunes, 2016).

Significative differences were observed after 30 minutes of intraperitoneal application of insulin when compared FDB and FDB+CEO with Ctrl (Table 2). The fall in glycemia induced by the intraperitoneal application of insulin occurs because the cells are stimulated to pick up the circulating glucose 15 to 20 minutes after the application and inhibit the glucose release by the liver. The counter-regulatory hormone, glucagon, is then secreted in the next 120 minutes to reestablish glycemia (Bonora et al., 1989; Wajchenberg et al., 1999).

None of the groups studied showed insulin resistance, once the groups reestablished the glycemia after 120 minutes. This resistance can occur by multiple factors. For example, when the body has a low body weight, it adapts to the restricted supply of calories provided by the diet and reduces the secretion of insulin so that it has greater availability of glucose for the cells to perform their vital functions (Smith et al., 1975). 
Following intraperitoneal glucose application in the glucose tolerance test, the glucose will reach its maximum peak 15-30 minutes after it is applied. The same phenomenon is observed after normal ingestion. In the digestive tract, the food undergoes the digestion processes and absorption, with carbohydrates being the main nutrients responsible for providing energy to the cells in the glucose form (Araújo \& Martel, 2009).

When added to fermented dairy beverage, the clove essential oil did not offer resistence to insulin and it promoted lowering plasmatic levels of glucose. That result corroborates literature data (Tu et al., 2014) that show the hypoglycemic efect of the clove essential oil.

When the blood glucose level increases, it activates the release of insulin by the $\beta$ cells, which then bind to the cells of the body to activate the signalling cascade, as the Phosphoinositide 3-kinases/serine/threonine kinase (PI3K/AKT) Pathway (Hopkins et al., 2020).

The PI3K/AKT pathway promotes glucose transport, glycogen and protein synthesis (Huang et al., 2018). The bioinformatics analysis carried out in this study showed the AKT1, PIK3CA, PIK3CB and PIK3R1 proteins as the leading genes. These genes are involved in the PI3K/AKT pathway. The PI3K plays a direct role in insulin signaling. AKT, among other functions, mediates the actions of insulin and regulates the uptake of glucose by means of glucose transporters in cells (Karadogan et al., 2018).

The passive facilitative glucose transporters (GLUTs) and the secondary active sodium-coupled glucose transporters (SGLTs) present in all cells then open their channels so that glucose can enter the cells and either be stored as glycogen or generate energy in the form of ATP (Machado, 1998).

The individual may present insulin resistance and/or glucose tolerance, obesity, diabetes, hyperglycemia, dyslipidaemia, hepatic steatosis, or hypertension. Since diabetes engages metabolic diseases, it will generate hyperglycemia, resulting from insulin resistance, secretion and action, and/or glucose intolerance (American Diabetes Association, 2016).

The glucose tolerance and insulin resistance tests in mice are critical to perform, as new foods increased in the human diet can lead to metabolic disorders throughout the lifespan (Vinué \& González-Navarro, 2015) and the genetic glucose transport proteins expression of SGLTs and GLUTs may also undergo modifications (Sampaio et al., 2016).

Possibly the clove essential oil present in the fermented dairy beverage regulated the expression of the main proteins in the PI3K/Akt pathway, which may have contributed to lower glycemic levels in the animals of the group FDB + CEO, obtained in the insulin sensitivity and glucose tolerance tests.

When evaluating ALT, AST and Albumin (Figure 2C) we obtain a result similar to that obtained by (Elkomy et al., 2018 ) in which rats treated with $200 \mathrm{mg} / \mathrm{kg}$ of body weight with clove essential oil, also showed no significant difference (p $<0.05)$, in these biochemical parameters. In the context of toxicity, ALT and AST are released and increase in plasma three times more than the baseline level (Xu et al., 2015)

The biochemical analysis of triglycerides, total cholesterol and HDL, in the group FDB+CEO did not differ significantly ( $\mathrm{p}<0.05$ ), in the Ctrl and FDB groups (Fig. 2D). These results corroborate the findings described by (Al-attar \& Zari, 2007) that evaluated the modulating effects of $5 \%$ essential clove oil on the physiological responses in non-diabetic Wistar rats, in which the biochemical parameters did not differ with the group Ctrl.

The absence of lesions in the hepatic tissue observed in this study can be affirmed by the normality of the biochemical parameters, because when food generates liver damage, when it is metabolized in the liver, the integrity and function of the hepatocytes are compromised. Liver integrity is assessed using the enzymes albumin, ALT and AST (Hall \& Cash, 2012; Xu et al., 2015) and functionality by HDL, cholesterol and triglycerides. 
In the histopathological evaluation, the dosage of $2 \mu \mathrm{l} / \mathrm{ml}$, the essential oil of cloves added to fermented dairy beverage, did not present evidence of alteration regarding inflammation, steatosis and fibrosis that was indicative of toxicity caused by its administration (Figure 3).

The importance of researching these cytokines is related to the inflammatory response in the liver, which is mainly mediated by TNF $\alpha$, IL1 $\beta$, IL6, which increase their concentrations in the body (Khalil et al., 2018). In order for the body to function properly, homeostasis between pro-inflammatory and anti-inflammatory cytokines is necessary, since the imbalance between them can cause irreversible disorders (Medzhitov, 2008).

A diet that included the clove essential oil attenuated a change in glucose concentration on the GTT compared to control diets with and without a fermented dairy beverage. This represents the first work evaluating how this beverage functions in animal organisms. Importantly, this work verified that this beverage has a promising functional potential.

\section{Final Considerations}

The results obtained in the insulin sensitivity and glucose tolerance tests suggest that the fermented dairy beverage with the Syzygium aromaticum essential oil reduced blood glucose levels these data were corroborated by bioinformatics analysis.

In the evaluation of physiological parameters there were no signs of toxicity in the mice during the experimental period.

Hepatic integrity of the mice was evaluated by biochemical parameters, analysis, histopathological analysis and expression of pro-inflammatory (IL1 $\beta$, IL6 and TNF $\alpha$ ) and anti-inflammatory (IL-10) cytokines.

This may indicate the functionality of the beverage and that it is possible to add it to the diet of individuals.

Future work should further explore the mechanisms by which clove essential oil regulates glucose sensing and metabolism. For example, bioactive molecules in clove oil can modulate the expression of glucose transport proteins, SGLTs and GLUTs, and proteins from the PIK3/Akt pathway, which are responsible for absorbing glucose through the intestine.

Further work is also needed to confirm the safety of clove essential oil in a fermented dairy beverage and exclude the possibility of defective gastrointestinal absorption-related mechanisms.

\section{Acknowledgments}

This study was financed in part by the Coordenação de Aperfeiçoamento de Pessoal de Nível Superior - Brasil (CAPES) - Finance Code 001.

We thank the Universidade Estadual de Montes Claros (UNIMONTES), Pró Reitoria de Extensão da Universidade Federal de Minas Gerais (UFMG), Pró Reitoria de Pesquisa da UFMG, Conselho Nacional de Desenvolvimento Científico e Tecnológico (CNPq) and the Fundação de Amparo à Pesquisa do Estado de Minas Gerais (FAPEMIG).

\section{References}

Agência Nacional de Vigilância Sanitária. (2015). Anvisa. Guia de Procedimentos para Pedidos de Inclusão e Extensão de Uso de Aditivos Alimentares e Coadjuvantes de Tecnologia de Fabricação na Legislação Brasileira. http://portal.anvisa.gov.br/alimentos/aditivos-alimentares

Al-attar, A. M., \& Zari, T. A. Z. (2007). Modulatory Effects of Ginger and Clove Oils on Physiological Responses in Streptozotocin-Induced Diabetic Rats. International Journal of Pharmacology, 3(1), 34-40. https://doi.org/10.3923/ijp.2007.34.40

Al-Okbi, S. Y., Mohamed, D. A., Hamed, T. E., \& Edris, A. E. (2014). Protective effect of clove oil and eugenol microemulsions on fatty liver and dyslipidemia as components of metabolic syndrome. Journal of Medicinal Food, 17(7), 764-771. https://doi.org/10.1089/jmf.2013.0033

American Diabetes Association. (2016). 2. Classification and Diagnosis of Diabetes. Diabetes Care, 39(1), S13-S22. https://doi.org/10.2337/dc16-S005 
Araújo, J. R., \& Martel, F. (2009). Regulação da absorção intestinal de glicose. Arquivos de Medicina, 23(2), 35-43.

Bao, C., Guo, J., Lin, G., Hu, M., \& Hu, Z. (2008). TNFR gene-modified mesenchymal stem cells attenuate inflammation and cardiac dysfunction following MI. Scandinavian Cardiovascular Journal, 42(1), 56-62. https://doi.org/10.1080/14017430701543556

Barbosa, I. A., Santos, E. M., Paraíso, A. F., Chagas, P. V. F., Oliveira, L. P., Andrade, J. M. O., Farias, L. C., Carvalho, B. M. A. de, de Paula, A. M. B., Guimarães, A. L. S., \& Santos, S. H. S. (2019). Liraglutide alters hepatic metabolism in high-fat fed obese mice: A bioinformatic prediction and functional analysis. Meta Gene, 20, 100553. https://doi.org/10.1016/j.mgene.2019.100553

Bonora, E., Moghetti, P., Zancanaro, C., Cigolini, M., Querena, M., Cacciatori, V., Corgnati, A., \& Muggeo, M. (1989). Estimates of in vivo insulin action in man: Comparison of insulin tolerance tests with euglycemic and hyperglycemic glucose clamp studies. Journal of Clinical Endocrinology and Metabolism, 68(2), 374-378. https://doi.org/10.1210/jcem-68-2-374

Brasil. (2003). Ministério da Agricultura Pecuária e Abastecimento. Instrução Normativa no 62, de 26 de agosto de 2003. Oficializa os Métodos Analíticos Oficiais para Análises Microbiológicas para Controle de Produtos de Origem Animal e Água. Diário Oficial Da República Federativa Do Brasil. http://extranet.agricultura.gov.br/sislegis-consulta/consultarLegislacao.do?operacao=visualizar\&id=2851

Brasil. (2005). Ministério da Agricultura Pecuária e Abastecimento. Instrução Normativa n. ${ }^{o}$ 16, de 23 de agosto de 2005 . Aprova o regulamento Técnico de Identidade $e$ Qualidade de Bebidas Láctea. Diário Oficial Da República Federativa Do Brasil. https://www2.cead.ufv.br/sgal/files/apoio/legislacao/legislacao6.pdf

Brasil. (2006). Ministério da Agricultura Pecuária e Abastecimento. Instrução Normativa ${ }^{\circ} 68$ de 12 de dezembro de 2006. Oficializa os Métodos Analíticos Oficiais Físico-Químicos, para Controle de Leite e Produtos Lácteos. Diário Oficial Da República Federativa Do Brasil. https://www.diariodasleis.com.br/busca/exibelink.php?numlink=1-77-23-2006-12-12-68

Brasil. (2007). Ministério da Agricultura Pecuária e Abastecimento. Instrução Normativa $n^{\circ} 46$, de 23 de outubro de 2007 . Regulamento Técnico de Identidade e Qualidade de Leites Fermentados. Diário Oficial Da República Federativa Do Brasil. http://www.cidasc.sc.gov.br/inspecao/files/2012/08/instruÇÃo-normativa-no-46-de-23-de-outubro-de-2007.pdf

Brasil. (2015). Ministério da Ciência Tecnologia e Inovação Conselho Nacional de Controle de Experimentação Animal. Normativas do CONCEA para produção, manutenção ou utilização de animais em atividades de ensino ou pesquisa científica. Lei, Decreto, Portarias, Resoluções (MCTI/CONCEA (ed.); 2nd ed.).

Brunt, E. M., Janney, C. G., Bisceglie, A. M. Di, Neuschwander-tetri, B. A., \& Bacon, B. R. (1999). Nonalcoholic Steatohepatitis : A Proposal for Grading and Staging the Histological Lesions. The American Journal of Gastroenterology, 94(9).

Cortés-Rojas, D. F., de Souza, C. R. F., \& Oliveira, W. P. (2014). Clove (Syzygium aromaticum): a precious spice. Asian Pacific Journal of Tropical Biomedicine, 4(2), 90-96. https://doi.org/10.1016/S2221-1691(14)60215-X

Dhama, K., Karthik, K., Khandia, R., Munjal, A., Tiwari, R., Rana, R., Khurana, S. K., Sana Ullah, Khan, R. U., Alagawany, M., Farag, M. R., Dadar, M., \& Joshi, S. K. (2018). Medicinal and therapeutic potential of herbs and plant metabolites / extracts countering viral pathogens - current knowledge and future prospects. Current Drug Metabolism, 19(3), 236-263. https://doi.org/10.2174/1389200219666180129145252

Di Cerbo, A., Morales-Medina, J. C., Palmieri, B., Pezzuto, F., Cocco, R., Flores, G., \& Iannitti, T. (2017). Functional foods in pet nutrition: focus on dogs and cats. Research in Veterinary Science, 112, 161-166. https://doi.org/10.1016/j.rvsc.2017.03.020

Elkomy, A., Aboubakr, M., Ibrahim, S., \& Abdelhamid, Y. (2018). Protective effects of Syzygium aromaticum oil ( Clove ) against acrylamide induced hepatic , renal, and testicular toxicity in rats. 6(1), 12-17. https://doi.org/10.14419/ijpt.v6i1.10972

Fan, S., Yin, Q., Li, D., Ma, J., Li, L., Chai, S., Guo, H., \& Yang, Z. (2020). Anti-neuroinflammatory effects of Eucommia ulmoides Oliv. In a Parkinson's mouse model through the regulation of p38/JNK-Fosl2 gene expression. Journal of Ethnopharmacology, 260 , 113016. https://doi.org/10.1016/j.jep.2020.113016

Farias, P. K. S. (2016). Elaboração de bebida láctea fermentada com adição de óleo essencial. Instituto de Ciências Agrárias - Universidade Federal de Minas Gerais(ICA-UFMG).

Figueiredo, J. S. B., Santos, G. L. M., Lopes, J. P. A., Fernandes, L. B., Silva, F. N., Faria, R. B., Rocha, A. C. S., Farias, P. K. S., Lima, W. J. N., Durães, C. A. F., Xavier, A. R. E. de O., Carvalho, B. M. A. de, Careli, R. T., Almeida, A. C. de, \& Brandi, I. V. (2019). Sensory evaluation of fermented dairy beverages supplemented with iron and added by Cerrado fruit pulps. Food Science and Technology, 39(2), 410-414. https://doi.org/10.1590/fst.32616

Food and Drug Administration FDA. (2018). Departament of Health \& Human Service. Code of Federal Regulations: Title 21 - food and drugs. Chapter - I food and drug administration. Department of health and human services. Subchapter B - food for human consumption (continued). Part 184 -direct food s. https://www.accessdata.fda.gov/scripts/cdrh/cfdocs/cfCFR/CFRSearch.cfm?fr=170.30

Hall, P., \& Cash, J. (2012). What is the Real Function of the Liver 'Function' Tests ? 81(August 2011), 30-36.

Hopkins, B. D., Goncalves, M. D., \& Cantley, L. C. (2020). Insulin-PI3K signalling: an evolutionarily insulated metabolic driver of cancer. Nature Reviews Endocrinology, 16(5), 276-283. https://doi.org/10.1038/s41574-020-0329-9

Huang, X., Liu, G., Guo, J., \& Su, Z. (2018). The PI3K/AKT pathway in obesity and type 2 diabetes. International Journal of Biological Sciences, 14(11), 1483-1496. https://doi.org/10.7150/ijbs.27173

Jørgensen, M. S., Tornqvist, K. S., \& Hvid, H. (2017). Calculation of glucose dose for intraperitoneal glucose tolerance tests in lean and obese mice. Journal of the American Association for Laboratory Animal Science, 56(1), 95-97. 
Karadogan, A., Arikiglu, H., Gokturk, F., Iscioglu, F., \& Ipekci, S. (2018). PIK3R1 gene polymorphisms are associated with type 2 diabetes and related features in the Turkish population. Advances in Clinical and Experimental Medicine, 27(7), 921-927. https://doi.org/10.17219/acem/68985

Khalil, A., Omran, H., \& Alsheikh, F. (2018). Balance of pro- and anti-inflammatory cytokines in livers of high fat diet rats exposed to fractionated gamma irradiation. BMC Research Notes, 11(1), 741. https://doi.org/10.1186/s13104-018-3851-2

Kwiatkowski, R. P., \& Antunes, M. D. (2016). Efeito da administração dos hormônios contrarreguladores sobre o perfil profile of mice undergoing glycemic insulin-induced hypoglycemia. Brazilian Journal of Surgery and Clinical Research, 17, 68-73.

Liu, B.-B., Luo, L., Liu, X.-L., Geng, D., Li, C.-F., Chen, S.-M., Chen, X.-M., Yi, L.-T., \& Liu, Q. (2015). Essential oil of Syzygium aromaticum reverses the deficits of stress-induced behaviors and hippocampal p-ERK/p-CREB/Brain-derived neurotrophic factor expression. Planta Medica, 81(03), 185-192. https://doi.org/10.1055/s-0034-1396150

Livak, K. J., \& Schmittgen, T. D. (2001). Analysis of relative gene expression data using real-time quantitative PCR and the 2- $\Delta \Delta \mathrm{CT}$ method. Methods, 25(4), 402-408. https://doi.org/10.1006/meth.2001.1262

Machado, U. F. (1998). Transportadores de glicose. Arquivos Brasileiros de Endocrinologia \& Metabologia, 42(6), 413-421. https://doi.org/10.1590/S000427301998000600003

Malone, M. H., \& Robichaud, R. (1962). A hippocratic screen for pure or crude drug materials. Lloydia, 25, 320-332.

Matthews, J. N., Altman, D. G., Campbell, M. J., \& Royston, P. (1990). Analysis of serial measurements in medical research. BMJ, 300(6719), 230-235. https://doi.org/10.1136/bmj.300.6719.230

Medzhitov, R. (2008). Origin and physiological roles of inflammation. Nature, 454(7203), 428-435. https://doi.org/10.1038/nature07201

Murakami, M., Okuyama, Y., Ogura, H., Asano, S., Arima, Y., Tsuruoka, M., Harada, M., Kanamoto, M., Sawa, Y., Iwakura, Y., Takatsu, K., Kamimura, D., \& Hirano, T. (2011). Local microbleeding facilitates IL-6- and IL-17-dependent arthritis in the absence of tissue antigen recognition by activated T cells. The Journal of Experimental Medicine, 208(1), 103-114. https://doi.org/10.1084/jem.20100900

Rines, A. K., Sharabi, K., Tavares, C. D. J., \& Puigserver, P. (2016). Targeting hepatic glucose metabolism in the treatment of type 2 diabetes. Nature Reviews Drug Discovery, 15(11), 786-804. https://doi.org/10.1038/nrd.2016.151

Sampaio, I. C., Medeiros, P. H. Q. S., Rodrigues, F. A. P., Cavalcante, P. A., Ribeiro, S. A., Oliveira, J. S., Prata, M. M. G., Costa, D. V. S., Fonseca, S. G. C., Guedes, M. M., Soares, A. M., Brito, G. A. C., Havt, A., Moore, S. R., \& Lima, A. A. M. (2016). Impact of acute undernutrition on growth, ileal morphology and nutrient transport in a murine model. Brazilian Journal of Medical and Biological Research, 49(10). https://doi.org/10.1590/1414-431x20165340

Santos, E. M., Farias, L. C., Santos, S. H. S., de Paula, A. M. B., Oliveira e Silva, C. S. de, \& Guimarães, A. L. S. (2017). Molecular finds of pressure ulcer: A bioinformatics approach in pressure ulcer. Journal of Tissue Viability, 26(2), 119-124. https://doi.org/10.1016/j.jtv.2017.01.002

Secchi, M. F., Crescenzi, M., Masola, V., Russo, F. P., Floreani, A., \& Onisto, M. (2017). Heparanase and macrophage interplay in the onset of liver fibrosis. Scientific Reports, 7(1), 14956. https://doi.org/10.1038/s41598-017-14946-0

Smith, S. R., Edgar, P. J., Pozefsky, T., Chhetri, M. K., \& Prout, T. E. (1975). Insulin secretion and glucose tolerance in adults with protein-calorie malnutrition. Metabolism, 24(9), 1073-1084. https://doi.org/10.1016/0026-0495(75)90101-8

Souza, K. S. S., Oliveira, S. P., Duarte, S. M., Brandi, I. V., Santos, S. H. S., Santos, E. M. S., Farias, P. K. S., Santos, H. O., \& Almeida, A. C. (2018). Standardization of the methodology for calorimetric analysis of a fermented milk drink. Caderno de Ciências Agrárias, 10(2), 61-63.

Szklarczyk, D., Gable, A. L., Lyon, D., Junge, A., Wyder, S., Huerta-Cepas, J., Simonovic, M., Doncheva, N. T., Morris, J. H., Bork, P., Jensen, L. J., \& Mering, C. von. (2019). STRING v11: protein-protein association networks with increased coverage, supporting functional discovery in genome-wide experimental datasets. Nucleic Acids Research, 47(D1), D607-D613. https://doi.org/10.1093/nar/gky1131

Tu, Z., Moss-Pierce, T., Ford, P., \& Jiang, T. A. (2014). Syzygium aromaticum L. (Clove) Extract regulates energy metabolism in myocytes. Journal of Medicinal Food, 17(9), 1003-1010. https://doi.org/10.1089/jmf.2013.0175

Vinué, Á., \& González-Navarro, H. (2015). Glucose and insulin tolerance tests in the mouse. In Humana Press (pp. 247-254). https://doi.org/10.1007/978-14939-2929-0_17

Vo, M.-C., Nguyen-Pham, T.-N., Lee, H.-J., Lakshmi, T. J., Yang, S., Jung, S.-H., Kim, H.-J., \& Lee, J.-J. (2017). Combination therapy with dendritic cells and lenalidomide is an effective approach to enhance antitumor immunity in a mouse colon cancer model. Oncotarget, 8(16), 27252-27262. https://doi.org/10.18632/oncotarget.15917

Wajchenberg, B. L., Santomauro, A. T. M. G., Nery, M., Santos, R. F., Silva, M. E. L. R., Ursich, M. J. M., \& Rocha, D. M. (1999). Resistência à insulina: métodos diagnósticos e fatores que influenciam a ação da insulina. Arquivos Brasileiros de Endocrinologia \& Metabologia, 43(2), 76-85. https://doi.org/10.1590/S0004-27301999000200003

Xu, Q., Higgins, T., \& Cembrowski, G. S. (2015). Limiting the Testing of AST. American Journal of Clinical Pathology, 144(3), 423-426. https://doi.org/10.1309/AJCPO47VAWYRIDHG 